Revista Brasileira de Meteorologia, v.24, n.1, 100-110, 2009

\title{
WEEKEND/WEEKDAY DIFFERENCES IN CONCENTRATIONS OF OZONE, NOX, AND NON- METHANE HYDROCARBON IN THE METROPOLITAN AREA OF SÃO PAULO
}

\author{
ROSIBERTO SALUSTIANO DA SILVA JÚNIOR, MARCIO GLEDSON LOPES DE OLIVEIRA AND \\ MARIA DE FÁTIMA ANDRADE
}

\author{
Universidade de São Paulo - USP, - IAG, São Paulo, SP.
}

rosiberto@model.iag.usp.br,marcio@model.iag.usp.br,mftandra@model.iag.usp.br

Received January 2008 - Accepted October 2008

\begin{abstract}
Ozone and inhalable particulate matter are the major air pollutants in the Metropolitan Area of São Paulo, Brazil, a region that has more than 19 million inhabitants and approximately 7 million registered vehicles. Proximity of roadways, adjacent land use, and local circulation are just some of the factors that can affect the results of monitoring of pollutant concentrations. The so-called weekend effect (higher ozone concentrations on weekends than on weekdays) might be related to the fact that concentrations of ozone precursors, such as nitrogen oxides (NOx) and Non Methane-Hydrocarbon (NMHC), are relatively lower on weekends. This phenomenon has been reported in some areas of the United States since the 1970s. The differences between the concentrations of ozone in period of weekend and weekday, were obtained from analysis of data hourly average of CETESB for 2004, studied the precursors to the formation of troposphere ozone, the meteorological variables and traffic profile for RMSP. Because of the proximity to sources of emissions from the station Pinheiros showed higher concentrations of $\mathrm{NO}$ and $\mathrm{NO}^{2}$ and greater variations to the periods weekend and weekday. With fewer vehicles circulating during the weekend, and consequently less emission of pollutants, it has cleaner air and less concentration of $\mathrm{NO}$ and $\mathrm{NO}^{2}$, there is the ideal setting to the formation of troposphere ozone, despite the lower concentration of $\mathrm{NO}^{2}$. The proximity with the source emissions, aided by the increased availability of solar radiation and the presence of ozone precursors, were factors conditions for the occurrence of weekend effect.
\end{abstract}

Keywords: Ozone formation, ozone weekend effect.

RESUMO: DIFERENÇA DE CONCENTRAÇÕES DE OZÔNIO, NOX E HIDROCARBONETOS NÃO METANO DURANTE PERÍODO DA SEMANA E FINAIS DE SEMANA, NA REGIÃO METROPOLITANA DE SÃO PAULO.

O ozônio e o material particulado inalável são os mais importantes poluentes do ar na região metropolitana de São Paulo (RMSP). Esta região possui em torno de 19 milhões de habitantes e aproximadamente 7 milhões de veículos registrados. O efeito final de semana sobre a concentração de ozônio, caracterizado por concentrações ozônio mais elevadas no fim de semana quando comparadas aos dias de semana, pode está relacionado às concentrações relativamente baixas dos precursores do ozônio tais como o óxido de nitrogênio (NOx) e os Hidrocarbonetos Não Metano (NMHC) nos finais de semana. As diferenças existentes entre as concentrações de ozônio nos períodos de fim de semana e dias da semana, foram obtidas a partir de analises médias dos dados horários da CETESB para o ano de 2004, foram estudados os precursores para a formação do ozônio troposférico, as variáveis meteorológicas e o perfil horário do trafego veicular para a RMSP. Devido a proximidade com as fontes de emissão a estação de Pinheiros apresentou maiores concentrações de $\mathrm{NO} \mathrm{NO}^{2}$ e maiores variações na concentração na comparação feita aos períodos. Com menos veículos circulando durante o período de final de semana e conseqüentemente menos emissão de poluentes, tem-se uma atmosfera mais limpa e menos concentração de $\mathrm{NO}_{\text {e }} \mathrm{NO}^{2}$, configurando uma situação mais favorável para a formação de ozônio troposférico, apesar da menor concentração de $\mathrm{NO}^{2}$. A proximidade da fonte de emissão de poluentes, auxiliados pela maior disponibilidade de radiação solar e a presença dos precursores da formação de ozônio, foram fatores condicionantes para a ocorrência do efeito final de semana.

Palavras-chave: Formação do Ozônio, Efeito final de semana. 


\section{INTRODUCTION}

The Metropolitan Area of São Paulo (MASP), located in southeastern Brazil, is considered one of the ten largest urban conglomerates in the world, with approximately 19 million inhabitants. In the MASP, ozone is the pollutant that most often surpasses the national standard for air quality (maximum mean hourly concentration, $160 \mu \mathrm{g} . \mathrm{m}^{-3}$ ). Over the last 10 years, ozone concentrations have remained fairly constant, with the exception of 2004, when ozone concentrations fell due to the meteorological conditions. The highest ozone concentrations occur between August and October, typically presenting a relatively short peak between 13:00 and 16:00 local time (LT)

In the MASP, ozone concentrations are approximately $24 \%$ higher on the weekends than on weekdays, whereas concentrations of ozone precursors and of inhalable particulate matter $\leq 10 \mu \mathrm{m}$ in diameter (PM10) are higher on weekdays. Pollution caused by ozone is a problem worldwide and is more intense away from large cities. Developing effective measures to reduce ozone concentrations is an issue that is quite complex. There is a need for programs designed to control ozone precursors, such as $\mathrm{NO} 2$ and hydrocarbons (HCs), in a nonlinear way (Martins et al., 2006).

Ozone is a pollutant that is not emitted directly by sources but is formed in the atmosphere through reactions among volatile organic compounds (VOCs) and nitrogen oxides (NOx) in the presence of solar radiation. Ozone is beneficial in the stratosphere, where it forms a protective layer against the harmful effects of the ultraviolet radiation. However, in the low troposphere, it has toxicological effects on living beings. In addition to a complex system of chemical reactions, meteorological and topographical factors determine where ozone concentrations will be the highest. Maximum ozone concentrations often occur in locales more distance of the source emissions (Finlayson-Pitts \& Pitts, 1997).

The formation of ozone in the troposphere begins with $\mathrm{NO}_{2}$ photolysis, after which the $\mathrm{NO}$ product quickly reacts with ozone to regenerate the $\mathrm{NO}_{2}$. Therefore, the ozone remains in a stationary state that depends on the speed of $\mathrm{NO}_{2}$ photolysis and on the $\mathrm{NO}^{2} / \mathrm{NO}$ ratio. If there were no other processes that transform $\mathrm{NO}$ into $\mathrm{NO}_{2}$, the concentration of ozone would not increase significantly. However, in the presence of VOCs, the ozone concentration increases after NO is converted to $\mathrm{NO}_{2}$ due to the formation of radicals. The speed of ozone formation depends on the amount and reactivity of each of those compounds (CETESB, 2002).

The aim of this study was to investigate the differences between weekend and weekday concentrations of tropospheric ozone in the MASP. In addition, we analyze effect that the weekend reduction in vehicular traffic - especially that of heavy duty diesel-fueled vehicles - has on ozone formation and consequently on concentrations of $\mathrm{NO}$ and $\mathrm{NO}_{2}$, which are involved in ozone dissociation.

\section{METHODOLOGY}

The locations of the MASP air quality monitoring stations from which the study data were collected are shown in Figure 1. The MASP is located at $23^{\circ} \mathrm{S}$ and $46^{\circ} \mathrm{W}$, in the southeastern region of Brazil. It has an area of $8.051 \mathrm{~km}^{2}$ and a population of 19 million inhabitants. The majority of the urban area lies within the São Paulo Sedimentary Basin, the principal valley following the Tietê River, which runs from east to west. The average altitude in the basin is $720 \mathrm{~m}$, and

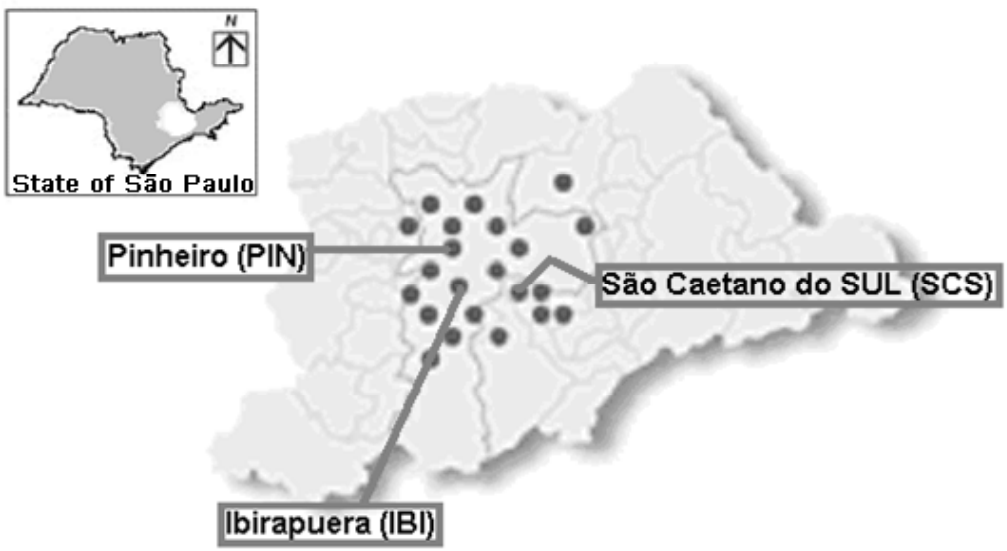

Figure 1 - Location of the air quality monitoring stations operated by the São Paulo State Environmental Protection Agency.

Source: CETESB, 2005 
there is an extensive floodplain. The basin is bordered on the north by the Cantareira mountain range, which also runs east to west and has peaks as high as 1,200 $\mathrm{m}$, and on the southeast by the Serra do Mar mountain range, which has altitudes that, in general, exceed $800 \mathrm{~m}$. The MASP is approximately $45 \mathrm{~km}$ from the Atlantic Ocean (CETESB, 2005).

The climate in the MASP can be summarized as dry in the winter and wet in the summer. From September to April, the climate is dominated by humid southern winds and frontal systems, resulting in precipitation and low-altitude clouds. During the winter, the formation of high-pressure systems in the eastern Atlantic Ocean and their subsequent movement to the north induces weak winds from the coast, strong thermal inversions of descendant air and clear skies. The annual precipitation is $1900 \mathrm{~mm}$, and the average temperature varies from $15^{\circ} \mathrm{C}$ to $22^{\circ} \mathrm{C}$ (Castanho, 1999; CETESB, 2004).

The relative contribution of each source of air pollution in the MASP can easily be seen in Figure 2, which was extracted from official data provided by the São Paulo State Companhia de Tecnologia de Saneamento Ambiental (CETESB, Environmental Protection Agency). As shown in the figure, light- and heavyduty vehicles are the main sources of $\mathrm{CO}$, total HCs and NOx. For sulphur oxides (SOx), industries and vehicles are major sources. For $\mathrm{PM}_{10}$, other factors contribute to the resuspension of soil particles and secondary aerosol formation. The relative contribution that each source makes to $\mathrm{PM}_{10}$ concentrations has been estimated from data obtained in a receptor model study (CETESB, 2005). In the official report, there are many uncertainties regarding the emission profiles of the stationary sources and regarding the total emissions.

The annual air pollutant production by these sources has recently been estimated as follows: $\mathrm{CO}, 1,700 \mathrm{t}$; $\mathrm{HCs}, 400 \mathrm{t}$; $\mathrm{NOx}$,

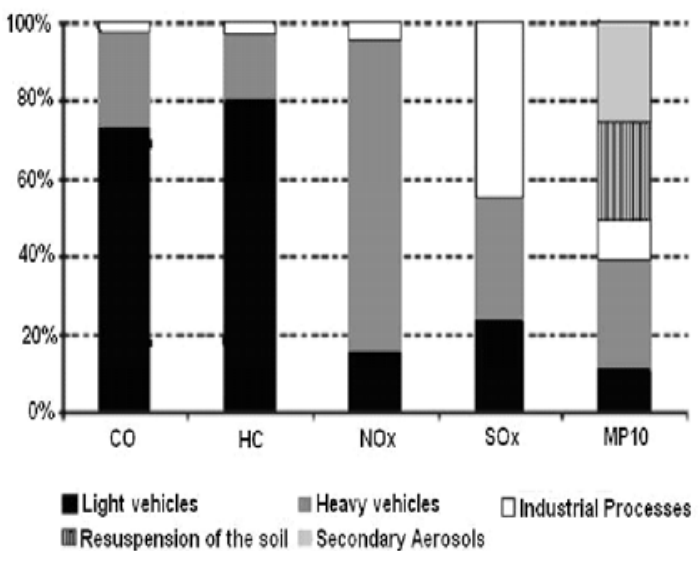

Figure 2 - Relative contributions of different sources to the total emission of pollutants in the Metropolitan Area of São Paulo in 2004.

Source: CETESB, 2004
$400 \mathrm{t}$; PM10, 65 t; and SOx, 40 t . In terms of total emissions, vehicles are responsible for approximately $98 \%$ of $\mathrm{CO}, 97 \%$ of $\mathrm{HCs}, 97 \%$ of NOx, $52 \%$ of PM10, and $57 \%$ of SOx. Of the vehicles in the MASP, approximately $6 \%$ run on diesel fuel and approximately $16 \%$ run on ethanol, whereas approximately $78 \%$ run on a mixture of $75-78 \%$ gasoline, by volume, and $22-25 \%$ ethanol, a blend commonly known as gasohol (CETESB, 2006).

Aerosols are solid or liquid particles in suspension in the atmosphere. Atmospheric aerosol particles are composed of a mixture of those of primary origin (direct emission from the source) and those of secondary origin (transformation of gases to particles). Aerosol particles range in diameter from just a few nanometers to tens of micrometers. Inhalable particulate matter is divided into two modes: the fine mode, in which the particles have aerodynamic diameters $\leq 2.5 \mu \mathrm{m}$; and the coarse mode, in which the particles have aerodynamic diameters $>2.5 \mu \mathrm{m}$ (Seinfeld and Pandis, 1998).

Basically, $\mathrm{PM}_{10}$ is composed of carbon compounds (carbonaceous and organic), sulphate, nitrates, ammonium, marine salts $(\mathrm{NaCl})$, trace elements from soil/dust ( $\mathrm{Al}, \mathrm{Si}, \mathrm{Ti}$, $\mathrm{Ca}$, and $\mathrm{Fe})$, heavy metals - mainly from industrial process $(\mathrm{Pb}$, $\mathrm{Zn}, \mathrm{Cu}, \mathrm{V}, \mathrm{Ni}, \mathrm{Cd}, \mathrm{Cr}$, and others) - and water. Carbonaceous aerosol is currently recognized as being the most abundant component in the urban aerosol mass (Turpin, 1999), as has also been observed in the MASP (Castanho and Artaxo, 2004). The primary sources are incomplete fossil fuel combustion, fossil fuel evaporation, industrial processes, and biogenic emission. In general, PM10 remains in the atmosphere from days to weeks. When particles greater than $10 \mu \mathrm{m}$ in diameter are formed, they are rapidly deposited by the effect of gravity (dry deposition). Favorable airflows can transport PM10 great distances, thereby influencing the chemistry and physics of the atmosphere not only on a local scale but also on a regional and even a global scale (Dockery and Pope, 1994). In the present study, we determined the surface concentration of PM10, together with the aerosol optical thickness (AOT), both of which will aid in the analysis of the attenuation of the available solar radiation for the photoreactions involved in the formation and dissociation of ozone (Castanho and Artaxo, 2004).

To achieve the objectives described, we analyzed the hourly variations in ozone concentration on weekdays and weekends for the year 2004 in the MASP. Data regarding the meteorological conditions and concentrations of ozone precursor gases were considered. We also analyzed concentrations of $\mathrm{CO}$, which is associated with vehicular emission, and of PM10, which is associated with AOT.

The formation of the ozone in the troposphere (table 01 ), begins with the $\mathrm{NO}_{2}$ photolysis, that is regenerate with reaction $\mathrm{NO}$ and $\mathrm{O}_{3}$. In that way, the $\mathrm{O}_{3}$ stays in stationary state that depends on the speed of $\mathrm{NO}_{2}$ photolysis and on the 
reason $\left[\mathrm{NO}_{2}\right] /[\mathrm{NO}]$. If there weren't other process that transform $\mathrm{NO}$ in $\mathrm{NO}_{2}$, the concentration of ozone would not increase significantly. However, that cycle can be broken due the different oxidations that happen in the atmosphere in the presence of the radical hydroxyl that usually interferes reacting with the NO producing $\mathrm{NO}_{2}$. It can highlight the presence of the volatile organic compounds, the concentrations of ozone increase once $\mathrm{NO}$ converted to $\mathrm{NO}_{2}$ due to the formation of radicals. The speed of ozone formation depends on the amount and of the reactivity of each one of those compounds (CETESB, 2002).

Ozone concentration data were gathered from the CETESB Air Quality Monitoring Stations Network.

Hourly data regarding ozone, $\mathrm{NO}, \mathrm{NO} 2, \mathrm{CO}$ and PM10 concentrations, as well as hourly meteorological data (wind speed, wind direction, air temperature, relative humidity, and solar radiation) were extracted from the 2004 CETESB database for the air quality monitoring stations located in the MASP districts Ibirapuera, Pinheiros, and São Caetano do Sul. Data for weekdays were separated from those for weekend days and were transformed into hourly average data. The period of study was from January 1 to December 31 of 2004, except for the portion of the study involving data collected from the Pinheiros station, which ran from June 29 to December 31 of 2004.

In order to represent ozone concentrations that are typically higher than the national air quality standard, we chose two air quality monitoring stations: Ibirapuera, which is $50 \mathrm{~m}$ from traffic; and Pinheiros, which is closer to a roadway with heavy traffic. Data for non-methane hydrocarbon (NMHC) was available only for the Sao Caetano do Sul station.

At the Pinheiros and Ibirapuera stations, the following parameters are habitually measured: $\mathrm{PM}_{10}, \mathrm{SO}_{\mathrm{x}}, \mathrm{NO}_{\mathrm{x}}$, ozone, $\mathrm{CO}$, wind direction, wind speed, relative humidity, temperature,

Table 01 - Main reactions of formation Troposphere Ozone through the cycle of the nitrogen and the reactions of oxidation that interfere in that cycle (SEINFELD and PANDIS, 1998).

\begin{tabular}{|c|c|c|}
\hline Nitrogen cycle - NOx & $\begin{array}{l}\mathrm{NO}_{2}+\mathrm{hn} \\
\mathrm{O}+\mathrm{O}_{2} \\
\mathrm{NO}+\mathrm{O}_{3}\end{array}$ & $\begin{array}{l}\left({ }^{\circledR} \mathrm{NO}+\mathrm{O}(\mathrm{I}<424 \mathrm{~nm})\right. \\
\left(\mathrm{O}_{3}\right. \\
\left(\AA \mathrm{NO}_{2}+\mathrm{O}_{2}\right.\end{array}$ \\
\hline $\begin{array}{l}\text { Oxidation of the Volatile Organics } \\
\text { Compounds - VOCs }\end{array}$ & $\begin{array}{l}\mathrm{RH}+\mathrm{OH} \cdot\left(+\mathrm{O}_{2}\right) \\
\mathrm{RO}_{2} \cdot+\mathrm{NO} \\
\mathrm{RO}++\mathrm{O}_{2} \\
\mathrm{RCHO}+\mathrm{OH} \cdot \\
\mathrm{RC}(\mathrm{O}) \mathrm{O}_{2} \cdot+\mathrm{NO}\end{array}$ & $\begin{array}{l}\left(\mathrm{RO}_{2} \cdot+\mathrm{H}_{2} \mathrm{O}\right. \\
\left(\mathrm{RO} \cdot+\mathrm{NO}_{2}\right. \\
\left(\mathrm{R}^{\prime} \mathrm{CHO}+\mathrm{HO}_{2} \cdot\right. \\
\left(\mathrm{RC}^{\circ}\right)_{2} \cdot+\mathrm{H}_{2} \mathrm{O} \\
\left(\mathrm{NO}_{2}+\mathrm{RO}_{2} \cdot+\mathrm{CO}_{2}\right.\end{array}$ \\
\hline $\begin{array}{l}\text { Oxidation of the Carbon } \\
\text { Monoxide }-\mathrm{CO}\end{array}$ & $\begin{array}{l}\mathrm{CO}+\mathrm{OH} \cdot \\
\mathrm{H} \cdot+\mathrm{O}_{2}+\mathrm{M} \\
\mathrm{NO}+\mathrm{HO}_{2}\end{array}$ & $\begin{array}{l}\text { (8) } \mathrm{CO}_{2}+\mathrm{H} \cdot \\
\text { (®) } \mathrm{HO}_{2}+\mathrm{M} \\
\text { (8) } \mathrm{NO}_{2}+\mathrm{OH} \cdot\end{array}$ \\
\hline Oxidation of the Methane $-\mathrm{CH}_{4}$ & $\begin{array}{l}\mathrm{CH}_{4}+\mathrm{OH} \cdot \\
\mathrm{CH}_{3}+\mathrm{O}_{2}+\mathrm{M} \\
\mathrm{CH}_{3} \mathrm{O}_{2} \cdot+\mathrm{NO} \\
\mathrm{CH}_{3} \mathrm{O} \cdot+\mathrm{O}_{2} \\
\mathrm{HO}_{2} \cdot+\mathrm{NO}\end{array}$ & $\begin{array}{l}\text { (8) } \mathrm{CH}_{3} \cdot \mathrm{H}_{2} \mathrm{O} \\
\text { (8) } \mathrm{CH}_{3} \mathrm{O}_{2} \cdot+\mathrm{M} \\
\text { (8) } \mathrm{CH}_{3} \mathrm{O} \cdot+\mathrm{NO}_{2} \\
\text { (8) } \mathrm{HCHO}+\mathrm{HO}_{2} \cdot \\
\text { (8) } \mathrm{OH} \cdot+\mathrm{NO}_{2}\end{array}$ \\
\hline $\begin{array}{l}\text { Oxidation of the Formaldehyde - } \\
\text { HCHO }\end{array}$ & $\begin{array}{l}\mathrm{HCHO}+\mathrm{hn} \\
\mathrm{HCHO}+\mathrm{hn} \\
\mathrm{HCHO}+\mathrm{OH} \cdot \circledast \mathrm{I} \\
\mathrm{HCO}+\mathrm{O}_{2} \\
\mathrm{H} \cdot+\mathrm{O}_{2} \\
\mathrm{HO}_{2}+\mathrm{NO}\end{array}$ & $\begin{array}{l}\text { (8) } \mathrm{H}_{2}+\mathrm{CO} \\
\left({ }^{\circledR} \mathrm{H}+\mathrm{HCO} \cdot\right. \\
\mathrm{O} \cdot+\mathrm{H}_{2} \mathrm{O} \\
\left(\circledR \mathrm{HO}_{2} \cdot \mathrm{CO}\right. \\
\left(\mathrm{HO}_{2} \cdot\right. \\
\left(8 \mathrm{OH} \cdot+\mathrm{NO}_{2}\right.\end{array}$ \\
\hline
\end{tabular}


atmospheric pressure, and solar radiation (total and ultraviolet). The methods employed in the measurement of the parameters are listed in Figure 3.

To characterize the relationship between each meteorological variable and the concentration of ozone, we performed a cluster analysis, gathering similar elements into separate groups. The first stage is to convert the data matrix, which is composed of $\mathrm{n}$ elements and variables ( $\mathrm{n}$, $\mathrm{x}$, and $\mathrm{p}$ ) into a matrix of distances or similarities, measuring the proximity between two elements. The grouping process allows the relationships to be represented in a dendrogram, which illustrates all stages of the process. The resulting groups are characterized by maximum homogeneity and maximum intragroup differentiation in relation to the selected variables. It is a technique of multivariate analysis used for interpretation of analytical data, that it consists of identifying groups of objects inside with similar properties of a great dataset (CASTANHO, 1999). Leaving of sample space $\mathrm{N}$ dimensions, the distances are calculated among all of the points (objects) of this space, with base in that information the variables will be contained (objects) with smaller distances, later the distances are calculated among the groups forming a new grouping level and like this successive times until that the last level is created containing all of the elements. For clustering, we used the Single Linkage technique, also known as the "nearest-neighbor" method, which is one of the simplest and most widely used cluster analysis techniques. The distance between groups was measured using Pearson's correlation coefficient.

To estimate the influence of AOT on solar radiation and consequently on ozone concentration, we studied the AOT of the atmospheric aerosols using data from the Aerosol Robotic Network (http://aeronet.gsfc.nasa.gov/), under the guidance of officials from the University of São Paulo Institute of Physics. The daily averages for total solar radiation and ultraviolet radiation for the month of September, 2004 were compared those for ozone concentrations in the same month. September of 2004 was chosen because the highest concentrations of ozone occurred during that month, and consequently the variations due to increases in AOT and decreases in the amount of radiation would be expected to be more evident.

\begin{tabular}{|ll|}
\hline PARAMETER & METHOD \\
\hline $\mathrm{PM}_{10}$ & B radiation \\
\hline $\mathrm{SO}_{x}$ & Pulsed fluorescence (ultraviolet) \\
\hline $\mathrm{NO}_{x}$ & Chemiluminescence \\
\hline $\mathrm{CO}$ & Non-dispersive infrared \\
\hline $\mathrm{HCs}$ & Gas chromatography/flame ionization \\
\hline Ozone & Ultraviolet \\
\hline NMHC & Flame ionization detector \\
\hline
\end{tabular}

Figure 3 - Measurement methods employed at the air quality monitoring stations in the MASP.

Source: CETESB, 2005

\section{RESULTS AND DISCUSSION}

During the period from January 1 to December 31 of 2004, weekdays were characterized by considerable movement of light-duty and heavy-duty vehicles, with two characteristic peaks (one in the morning and the other in the afternoon), whereas the weekend days were characterized by less movement of light-duty and (especially) heavy-duty vehicles, together with a change in the pattern of vehicular circulation - the traffic being more homogeneously distributed over the course of the day. Concentrations of $\mathrm{NO}_{2}$ and ozone were higher on weekend days, although NO concentrations were higher on weekdays. One hypothesis is that the lower NO emissions (resulting from the reduction in heavy-duty vehicular traffic) create a scenario in which the $\mathrm{VOC} / \mathrm{NO}_{\mathrm{x}}$ ratio favors ozone formation. Many previous studies have shown that the atmosphere over the MASP is VOC-limited due to the high $\mathrm{NO}_{\mathrm{x}}$ emission by heavy-duty vehicles (Martins et al., 2006; Sanchez-Ccoyllo et al., 2007).

The principal meteorological conditions analyzed were wind speed, wind direction, temperature, relative humidity, solar radiation, and ultraviolet radiation. The objective of this analysis was to evaluate the influence that meteorological conditions might have on ozone concentrations, bearing in mind that solar radiation is the limiting factor for ozone formation. Due to the proximity of the air quality stations, the measurements of meteorological variables were considered representative for the two stations, Ibirapuera and Pinheiros, because no change the direct and wind speed and solar radiation (CETESB, 2005).

Figure 4 shows the average wind speed cycle of for weekdays and weekend days at the Ibirapuera station. The maximum wind speed occurred during the daytime periods (maximum at 17:00 LT of approximately $1.6 \mathrm{~m} / \mathrm{s}$ for the weekdays and weekends). Stronger winds are associated with greater horizontal transport of pollutants between 08:00 LT and 20:00 LT Less horizontal transport of the pollutants is observed when the winds are weaker (from 00:00-09:00 LT and 20:00-23:00 LT) due to the cycle of total solar radiation, which is inversely proportional to the concentration of ozone. No significant difference was found between weekdays and weekend days in terms of wind speed.

The average diurnal cycles of temperature and relative humidity at the Ibirapuera station are presented in Figure 5. There was a tendency toward higher values for temperature and relative humidity on weekend days.

Solar radiation is an important variable in the study of ozone formation, since it is responsible for the photolysis of $\mathrm{NO}_{2}$ and consequently for the formation of ozone. The average cycle of the total solar radiation is presented in Figure 6 for the Ibirapuera Station. There were no significant differences between weekday and weekend day values for solar radiation 
(total or ultraviolet), the maximum values (approximately 550 $\mathrm{W} . \mathrm{m}^{-2}$ ) occurring at 13:00 LT. Ultraviolet radiation presented greater availability at 13:00 LT, which is the most favorable time for the formation of ozone (the dissociation of $\mathrm{NO}_{2}$ occurs at wavelengths shorter than $0.4 \mu \mathrm{m}$ ).

Figure 7 presents a positive correlation $(r=0.64)$ between ozone concentration and total solar radiation. Ozone concentrations exceeded the air quality standard when the level of solar radiation topped $500 \mathrm{~W} \cdot \mathrm{m}^{-2}$, a situation in which there is a greater probability of $\mathrm{NO} 2$ dissociation for the formation of ozone. In its annual air quality report for the year 2002, CETESB reported a higher number of instances in which the ozone concentration exceeded the air quality standard and the level of solar radiation was above $500 \mathrm{~W} \cdot \mathrm{m}^{-2}$.

To characterize the relationship between each meteorological variable and the concentration of ozone and ozone precursors, two cluster analyses were performed (for the Ibirapuera and Pinheiros stations; Figure 8). For the Ibirapuera station, the variables analyzed clearly fell into two groups: one consisting of temperature, solar radiation, and

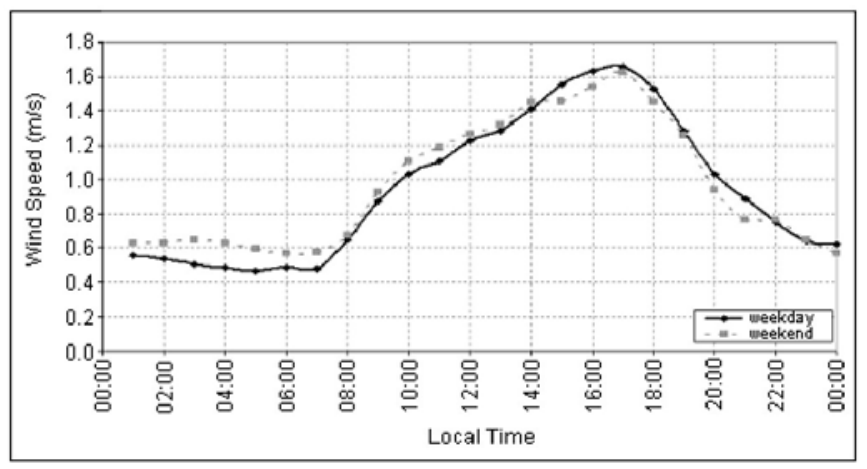

Figure 4 - Daily average cycle of wind speed at the Ibirapuera station in 2004

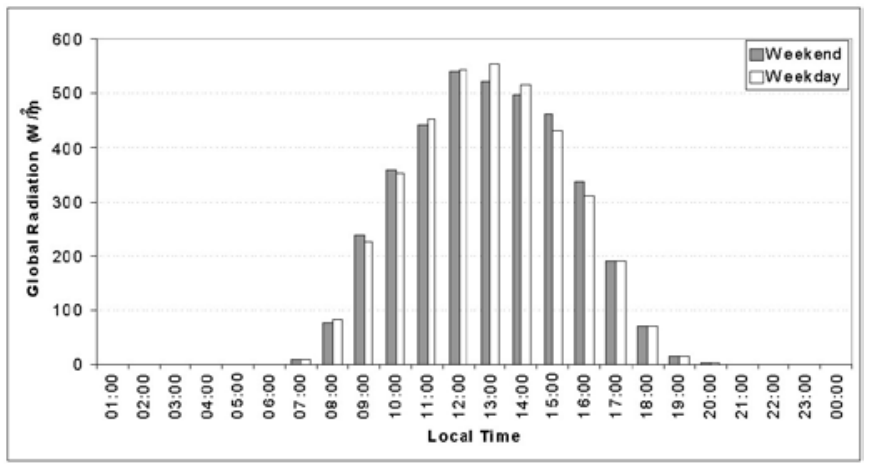

Figure 6 - Average diurnal cycle of total solar radiation at the Ibirapuera station in 2004 ozone; and the other consisting of $\mathrm{CO}, \mathrm{NO}_{2}, \mathrm{NO}$, relative humidity, atmospheric pressure, and PM10. This illustrates that solar radiation and temperature correlate positively with ozone concentration, whereas the variables in the other group (ozone precursors and primary pollutants) correlate negatively with ozone concentration. For the Pinheiros station, the results were very similar, although the variables fell into three groups: temperature, solar radiation and ozone; $\mathrm{CO}, \mathrm{NO}, \mathrm{NO}_{2}$ and $\mathrm{PM}_{10}$; and atmospheric pressure and relative humidity.

Monthly average ozone concentrations and solar radiation levels (Figure 9) at the Pinheiros and Ibirapuera stations were analyzed in an attempt to identify the months that are associated with higher ozone concentrations and higher levels of solar radiation. The months August, September, and October presented the highest concentrations of ozone, accompanied by a marked increase of the solar radiation values. The annual cycles of ozone concentration are similar to those of solar radiation levels, indicating that solar radiation is the meteorological variable of greatest importance in the formation of the ozone.

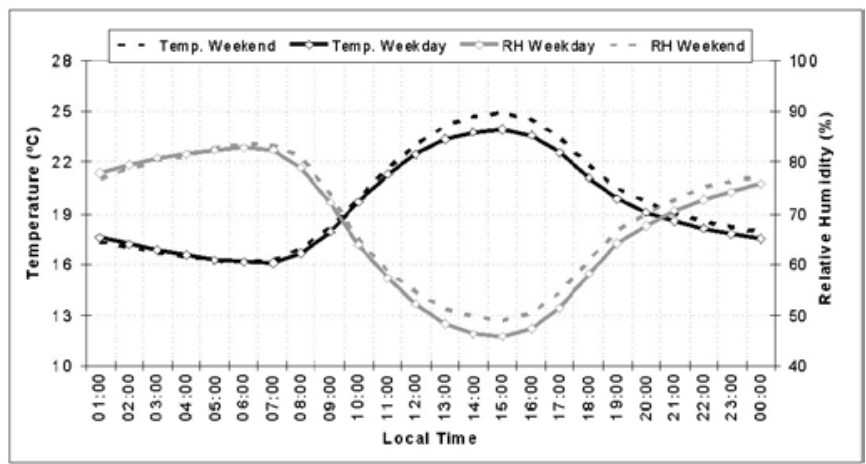

Figure 5 - Daily average cycle of temperature and relative humidity at the Ibirapuera station in 2004

Legend: Temp, temperature; $\mathrm{RH}$, relative humidity

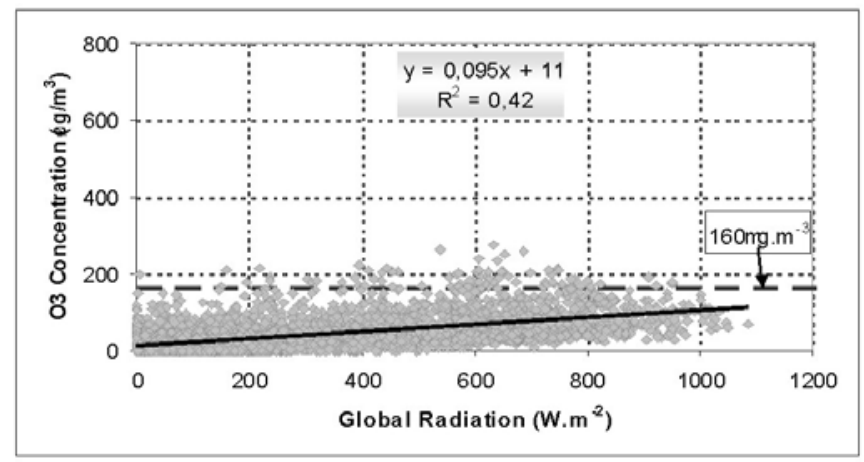

Figure 7 - Correlation between ozone concentration and total solar radiation at the Ibirapuera station in 2004 
To test the hypothesis that $\mathrm{PM}_{10}$ influences $\mathrm{NO}_{2}$ photolysis and consequently ozone formation, we analyzed temporal variations in $\mathrm{PM}_{10}$ concentrations. The lowest values were registered at 12:00 LT, a finding that is attributable to the greater dispersion of pollutants by the stronger midday winds (Figure 4), together with the expansion of the planetary boundary layer.

At the Pinheiros and Ibirapuera stations (Figure 10), $\mathrm{CO}$ and $\mathrm{PM}_{10}$ concentrations presented similar behavior, both peaking at 08:00 LT and 14:00 LT, the differences being associated with the greater proximity of the Pinheiros station to the sources of vehicular emissions. During the weekend the concentrations of PM10 are smaller, what could be associated to a clear atmosphere and consequently larger amount of solar radiation would be available for the photolysis of $\mathrm{NO}_{2}$.

The inversely proportional relationships between the AOT of each atmospheric aerosol and ozone concentration, as well as that observed between solar radiation and ozone concentration, are shown in Figures 11a and 11b, respectively. Due to the high concentrations of ozone in the month of September of 2004, small variations were evident. The higher AOTs occurring in the MASP from September 13 to 19 induced a decrease in the amount of solar radiation that reached the terrestrial surface, decreasing the amount of photolytic reactions in the low troposphere and thereby accounting for the lower ozone concentrations.

Figure 12 shows the inversely proportional relationship between $\mathrm{NO}$ and ozone, as determined in the cluster analysis. It is of note that the concentration of NO decreased between 00:00 LT and 06:00 LT, and the concentration of ozone therefore remained constant. Another characteristic to be taken into consideration is that at that interval of hours the atmosphere is stable, the planetary boundary being lower and the winds being weaker.

Weekday and weekend concentrations of ozone were higher the Ibirapuera station than at the Pinheiros station, a finding that can be explained by the lower concentrations of NO observed at the Ibirapuera station. At the Pinheiros station, a characteristic increase in the concentration of $\mathrm{NO}$ occurred twice a day (at 08:00 LT and 19:00 LT) on weekdays, which
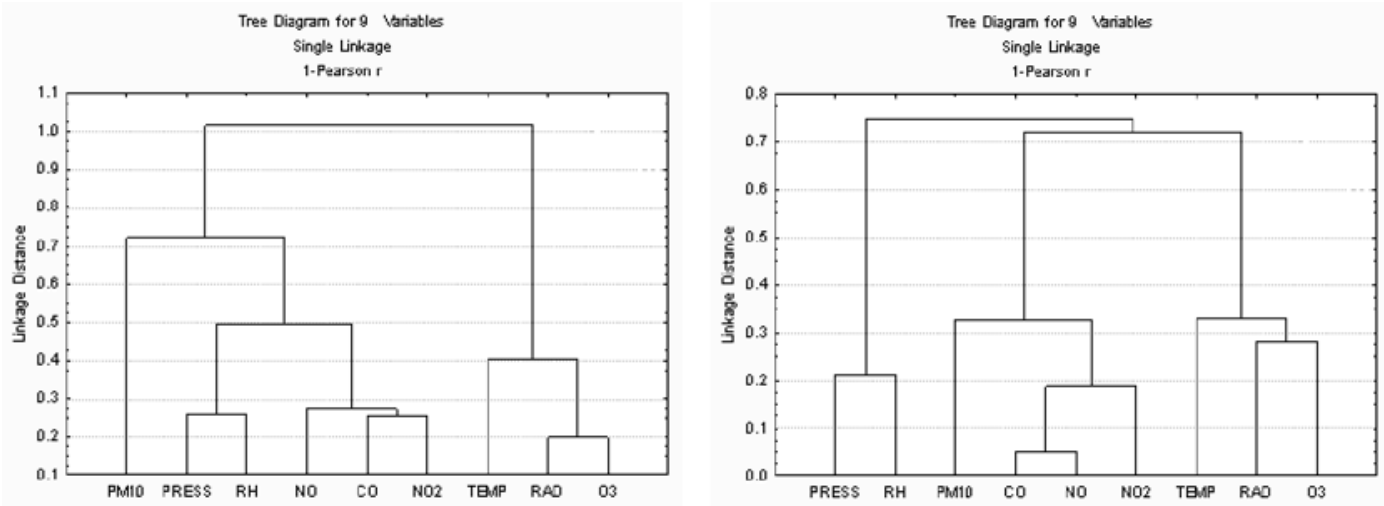

Figure 8 - Cluster analysis of meteorological and air quality parameters at the (a) Ibirapuera and (b) Pinheiros stations Legend: PRESS, (atmospheric) pressure; RH, relative humidity; TEMP, temperature; RAD, (solar) radiation;

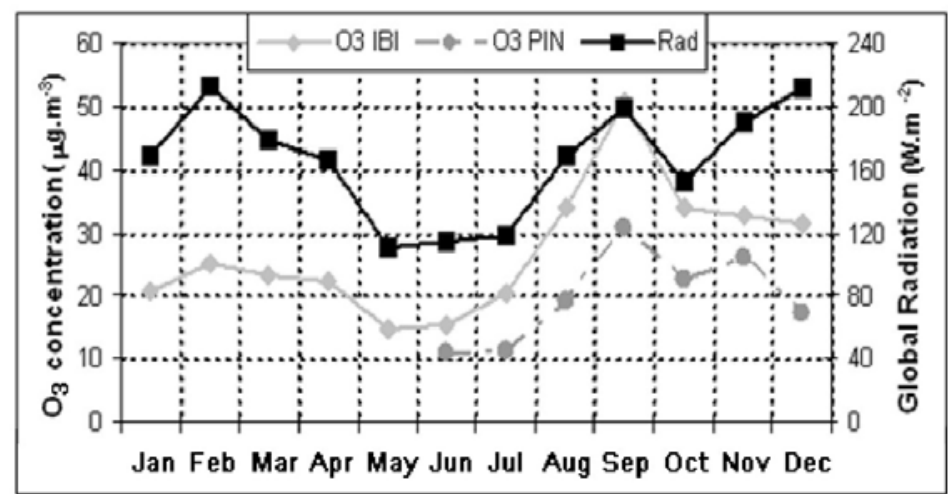

Figure 9 - Annual cycle of ozone concentration and solar radiation (Rad) at the Ibirapuera (IBI) and Pinheiros (PIN) stations in 2004 
can be attributed to the increase in the flow of vehicles that are the main sources of NO, as well as to the more stable meteorological conditions. On weekdays, the concentration of $\mathrm{NO}$ is, on average, $27 \%$ higher than it is on the weekend, which affects the concentrations of ozone, the mean values of which were $24 \%$ higher than those recorded on weekend days.

Contrary to what was observed at the Pinheiros station, where weekend concentrations of ozone decreased, no significant differences between weekday and weekend ozone concentrations were observed at the Ibirapuera station. One explanation for the lack of a difference between the two periods is that the Ibirapuera station is more distant from the sources of ozone precursors (vehicular traffic). The reactions take decrease the concentration of ozone (it isn't near street of high traffic), comparing the two stations in agreement with the figure 12 , the Ibirapuera station presents smaller values of NO due to largest distance of the source emission, what reduces the frequency of reactions $\left(\mathrm{NO}+\mathrm{O}_{3} \Rightarrow \mathrm{NO}_{2}+\mathrm{O}_{2}\right.$ ), having more accumulates of $\mathrm{O} 3$ in the atmosphere, still in that figure 12 it can be made an

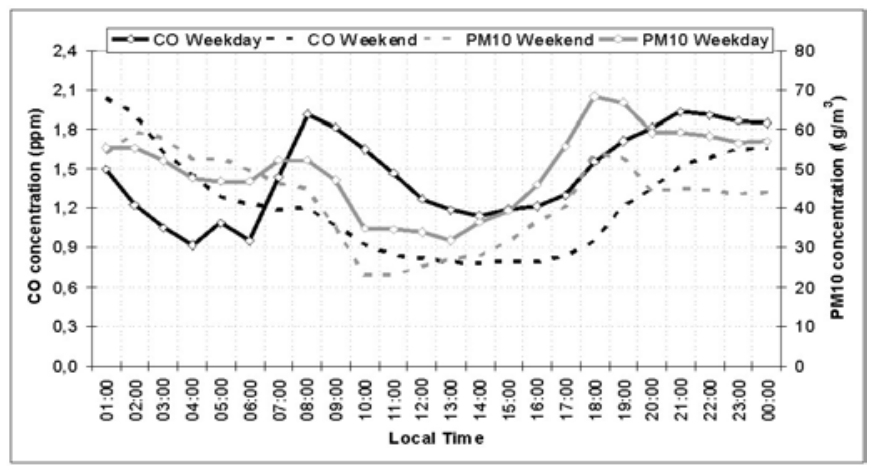

a) analogy that to smallest $\mathrm{NO}$ concentration, due to decrease of the vehicles traffic during days of weekends, trend of relationship with larger concentrations of O3. In Figure 12, it can be observed that the cycle of mean ozone concentration presented a peak on weekdays at 14:00 LT (74.5 $\mu \mathrm{g} . \mathrm{m}^{-3}$ at Ibirapuera and 55.2 $\mu \mathrm{g} . \mathrm{m}^{-3}$ at Pinheiros). On weekend days, the concentration was lower and the ozone concentration peaked at 15:00 LT (71.3 $\mu \mathrm{g} . \mathrm{m}^{-3}$ at Ibirapuera and $59.7 \mu \mathrm{g} . \mathrm{m}^{-3}$ at Pinheiros).

Figure 13 shows that, at the Ibirapuera station, NO2 concentrations were lower and ozone concentrations were higher than at the Pinheiros station, which reinforces the clean conditions hypothesis, and decrease of the reactions for oxidation because of the decrease of the NO concentration, it would help to a larger formation and accumulate on troposphere. A marked decrease in $\mathrm{NO}_{2}$ concentration was observed in the early morning hours, due to the lower volumes of vehicular traffic. However, weekday NO2 concentrations at the Ibirapuera station (with two characteristic peaks of $72.1 \mu \mathrm{g} . \mathrm{m}^{-3}$ at 10:00 LT and $75.4 \mu \mathrm{g} . \mathrm{m}^{-3}$ at 19:00 LT) were, on average, $20 \%$ higher than

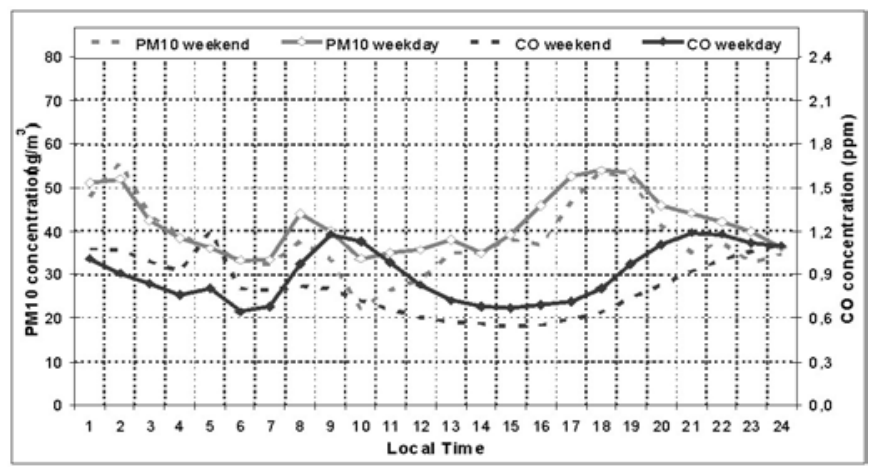

b)

Figure 10 - Daily average cycle of $\mathrm{CO}$ and $\mathrm{PM}_{10}$ concentrations at the (a) Pinheiros and (b) Ibirapuera stations in 2004

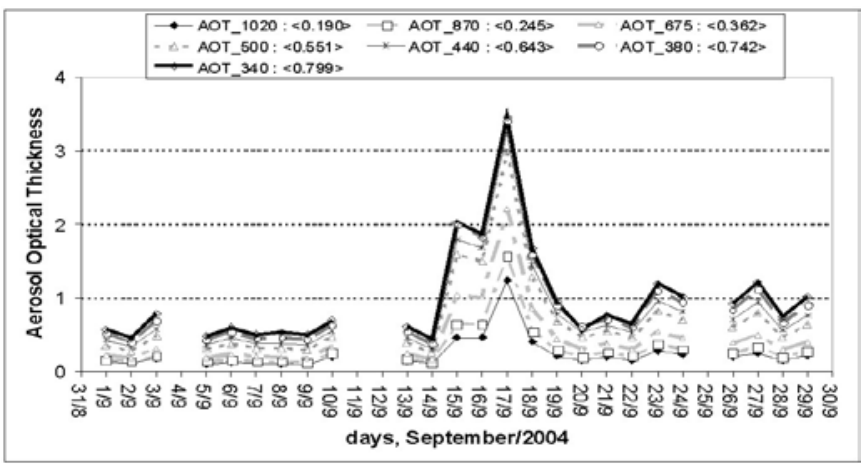

a)

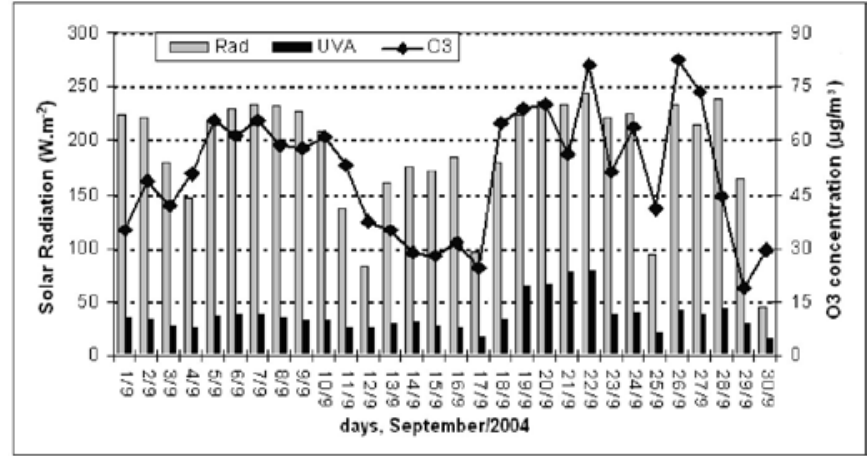

b)

Figure 11 - Variation in AOT, data source AERONET project NASA http://aeronet.gsfc.nasa.gov (a) in relation to the daily average for total solar radiation and ozone concentration, as well as daily accumulated ultraviolet radiation (b), in September, 2004

Legend: Rad, (solar) radiation; UVA, ultraviolet A 
the weekend concentrations observed at the Pinheiros station.

An explanation for the fact that the concentration of ozone was, on average, $24 \%$ higher on the weekends, at both stations, is that the ozone precursor ratios differed between weekdays and weekend days. Although concentrations of $\mathrm{NO}_{2}$ were lower (on the order of $30 \mu \mathrm{g} . \mathrm{m}^{-3}$ lower), there was a more accentuated (on the order of $50 \mu \mathrm{g} . \mathrm{m}^{-3}$ ) decrease in the concentration of NO. Due to the proximity of the source of $\mathrm{NO}_{\mathrm{x}}$ emission, the ozone produced is quickly consumed by the high concentration of NO. Due to the lower $\mathrm{NO}_{\mathrm{x}}$ concentrations on weekend days, when the atmosphere is also cleaner (lower concentrations of $\mathrm{PM}_{10}$ and $\mathrm{CO}$ ), there might be greater photolysis of $\mathrm{NO}_{2}$ and a consequent increase in the concentration of ozone and more accumulate of $\mathrm{O}_{3}$ due to smaller $\mathrm{NO}$ concentration.

Figure 14 presents the variation in NMHC and ozone concentrations at the São Caetano do Sul station. There was a characteristic peak at approximately 08:00 LT and an increase beginning at 18:00 LT, both associated with greater flow of vehicles. But it would be interesting to have that information for

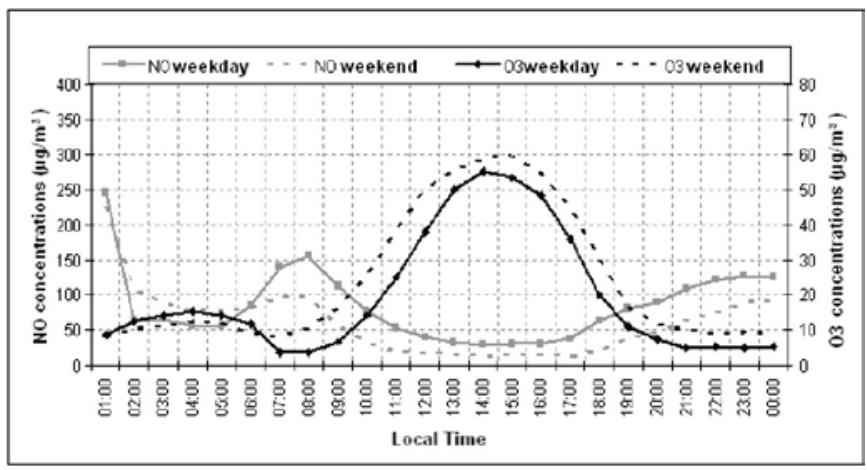

a) the stations of Pinheiros and Ibirapuera to have with accuracy the impact of the oxidation of NMHC in the formation and accumulation of troposphere ozone, however the figure 14 located in RMSP serves as indicative of the behavior of the hourly evolution of the concentration of HCNM, showing that during weekday the concentration is lightly larger than the days of weekends, validating the hypothesis that during the weekday there is a larger emission of pollutant, causing a light increase in the reactions for oxidation of NMHC that would explain the increase in the concentration of $\mathrm{NO} 2$, but no enough to increase the concentration of $\mathrm{O}_{3}$ due to the larger $\mathrm{NO}$ concentration.

At the Pinheiros station, the concentration of ozone was generally higher (by approximately $24 \%$ ) on weekend days than on weekdays, whereas there was no difference between weekdays and weekdays in terms of the ozone concentrations observed at the Ibirapuera station. The differences observed at the Pinheiros station are associated with the characteristics of the local measurements, especially with the proximity of heavily-traveled roadways. Similar results were found by Qin et

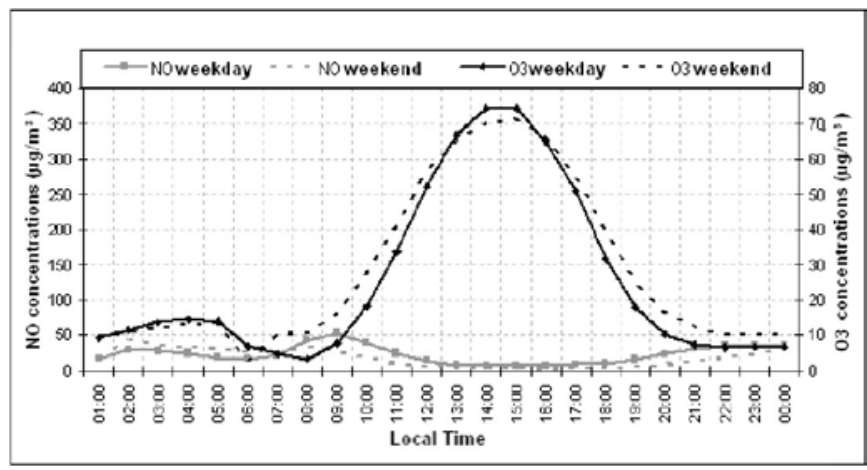

b)

Figure 12 - Daily average cycle of NO and ozone concentrations at the (a) Pinheiros and (b) Ibirapuera stations in 2004

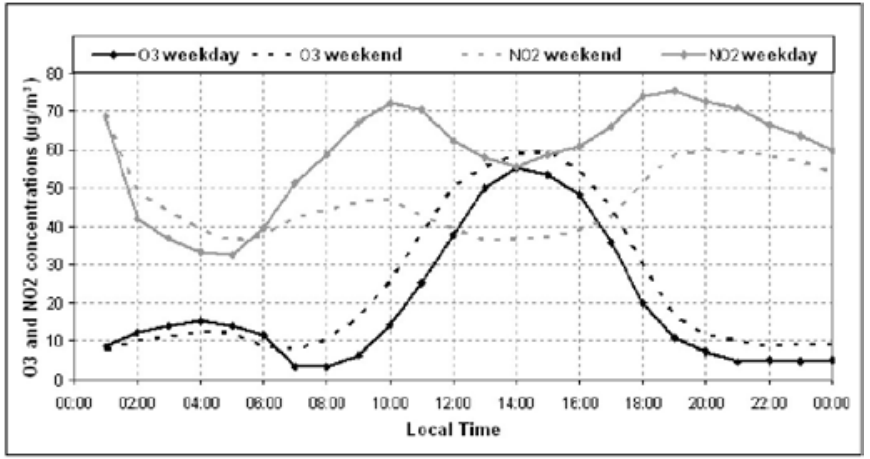

a)

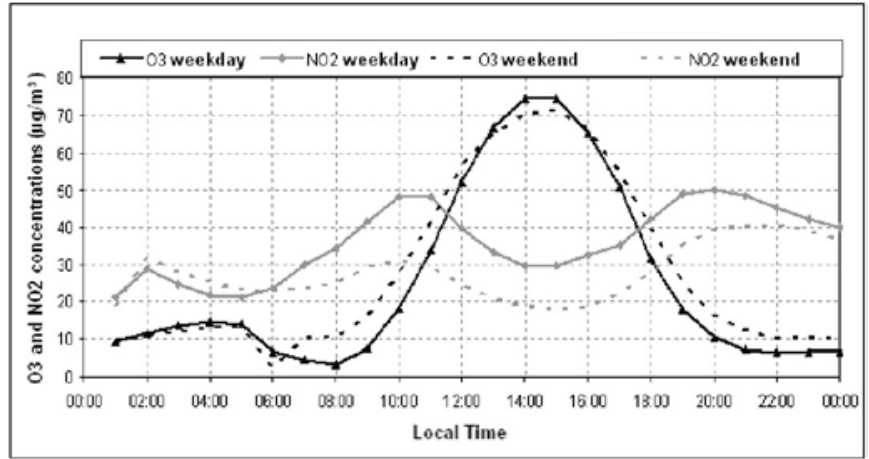

b)

Figure 13 - Daily average cycle of $\mathrm{NO}_{2}$ and ozone concentrations at the (a) Pinheiros and (b) Ibirapuera stations in 2004 


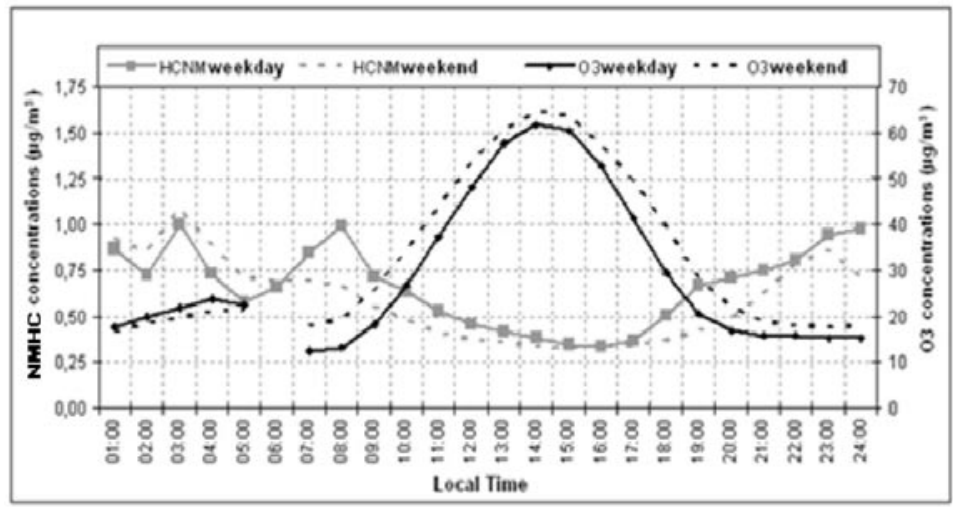

Figure 14 - Daily average cycle of NMHC and ozone concentrations at the São Caetano do Sul station in 2004

al. (2004) in a study conducted in southern California, in which ozone concentrations were also found to be higher on weekend days than on weekdays.

\section{CONCLUSION}

The formation of ozone presents a strong relationship with meteorological conditions. In large urban centers, high emissions of ozone precursors are associated with the burning of fossil fuels by light- and heavy-duty vehicles. The resulting high concentrations of ozone in the atmosphere are harmful to human health and to vegetation (EPA, 1997a).

The cluster analysis, based on the correlation coefficient as a measure of distance, effectively validated the data evaluated and allowed us to analyze the direct relationships that solar radiation and air temperature have with ozone concentration, as well as the inverse relationship between $\mathrm{NO}_{\mathrm{x}}$ concentrations and ozone concentration. We also found that wind speed, relative humidity, NMHC, and atmospheric pressure present weak relationships with ozone concentration.

Based on the analysis of data from two different stations, we concluded that the distance from road traffic affected the behavior of average ozone concentrations. Motivated by the largest formation of $\mathrm{O} 3$ due to smaller presence of atmospheric aerosols and larger accumulation of ozone due to smaller concentration of $\mathrm{NO}$ reacting with $\mathrm{O}_{3}$.

The number of incidents in which ozone concentration exceeded the air quality standards was higher at the Ibirapuera station, which is from the vehicular traffic, than at the Pinheiros station, which is near a roadway with heavy traffic. This can be attributed to the fact that, at the latter station, the concentrations of NO were higher, and the ozone was therefore consumed by the NO.
At the Pinheiros station, ozone concentrations were higher on weekend days than on weekdays, a finding that is associated with the decreased volume of vehicular traffic and, consequently, a $\mathrm{VOC} / \mathrm{NO}_{\mathrm{x}}$ ratio that was more favorable to ozone formation.

The results show that there was weekend effect due decrease of emissions and more Solar Radiation available, that is more favorable the ozone formation. Some situations are required for that occur weekend effect, rate VOCs / $\mathrm{NO}_{\mathrm{x}}$, distance from sources of emissions, and availability of precursors of ozone and solar radiation. Other studies show the occurrence of the weekend effect for some area in the North America since 1970 Cleveland et al., 1974; Lebron, 1975; Elkus and Wilson, 1977).

This work provides important information for academic studies regarding daily variation of the $\mathrm{O} 3$ concentration and their precursors, as well as the meteorological variables influence on its concentration. This study also established parameters for future studies on concentration levels of $\mathrm{O} 3$ for periods of the weekend and weekday. According to the current measurement it is possible to know if the concentration is above or below the standards for the RMSP.

\section{ACKNOWLEDGMENTS}

This study received financial support in the form of grants from the Coordenação de Aperfeiçoamento de Pessoal de Nível Superior (CAPES, Coordination of the Advancement of Higher Education), the Conselho Nacional de Desenvolvimento Científico e Tecnológico (CNPq, National Council for Scientific and Technological Development), and the Fundação de Amparo à Pesquisa do Estado de São Paulo (FAPESP, Foundation for the Support of Research in the State of São Paulo). The authors are grateful for CETESB for the air quality data provided. 


\section{REFERENCES}

ALTSHULER, S.L., ARCADO, T.D., LAWSON, D.R. Weekday vs. weekend ambient ozone concentrations: discussion and hypotheses with focus on northern California. Journal of the Air and Waste Management Association 45, 967-972, 1995.

BRAGA, A.; PEREIRA, L. A. A.; SALDIVA, P. H. N. Air pollution and effects on human health. Paper presented at the event of Sustainability in the generation and use of energy, UNICAMP, 18 to 20 February/2002 (http://libdigi. unicamp.br/document/?code=1039).

CASTANHO, A.D.A. The Quantitative Determination of sources of particulate matter in the atmosphere of São Paulo city, MSc (Institute of Physics - USP), September 1999.

CASTANHO, A.D.A. Optical properties of aerosols and particles of a new methodology for obtaining thick optical satellite above São Paulo, Ph.D. thesis (Institute of Physics - USP), 2005.

CETESB - ENVIRONMENTAL PROTECTION AGENCY OF SÃO PAULO; Report of air quality in the state of Sao Paulo, 2005.

CETESB; Study of Tropospheric Ozone in São Paulo Metropolitan Region; 96th Annual Conference \& Exhibition "Energy, Economic and Global Challenges, San Diego/EUA; 2003.

CETESB; Study of Tropospheric Ozone in São Paulo Metropolitan Region; 2002.

CLEVELAND, W.S., GRAEDEL, T.E., KLEINER, B., WARNER, K.L. Sunday and workday variations in photochemical air pollutants in New Jersey and New York. Science 186, 1037-1038, 1974.

DOCKERY,D.W., POPE,C.A. Acute Respiratory Effects of Particulate Air Pollution, Annual Review of Public Health, Vol. 15, 107-132, 1994.

ELKUS, B., WILSON, K.R., 1977. Photochemical air pollution: weekend-weekday differences. Atmospheric Environment 11, 509-515.
EPA - ENVIRONMENTAL PROTECTION AGENCY OF NEW SOUTH WALES GOVERNMENT, NSW State of the Environment Report 1997, NSW Environment Protection Authority, Sydney, 1997a [available at www.epa.nsw.gov. au/soe/97/index.htm].

FINLAYSON-PITTS, B.J. \& PITTS, J.N. Jr. Tropospheric Air Pollution: Ozone, Airborne Toxics, Polycyclic Aromatic Hydrocarbons, and Particles; Science; vol. 276; 1997; www. sciencemag.org.

FINLAYSON - PITTS, B.J. \& PITTS, J. N. Jr. Atmospheric Chemistry of Tropospheric Ozone Formation. Scientific and Regulatory Implications. Air \& Waste, 43, 1091, 1993;

FREITAS, E. D. Local circulations in Sao Paulo and effect on the dispersion of pollutants. Ph.D. Thesis (Institute of Astronomy, Geophysics and Atmospheric Sciences - USP), São Paulo, 2003.

IPCC2001 - Intergovernmental Panel on Climate Change. A plan for a Research Program on Aerosol Radiative forcing and climate change. Natl. Acad. Press., Washington, D.C., 2001.

LEBRON, F., 1975. A comparison of weekend-weekday ozone and hydrocarbon concentration in Baltimore-Washington metropolitan area. Atmospheric Environment 9, 861-863.

MARTINS, M.H.R.B.; ANAZIA, R.; GUARDANI, M.L.G.; LACAVA,C.I.V.; ROMANO,J.; SILVA, S.R. Evolution of air quality in the São Paulo metropolitan area and its relation with public policies; Int. J. Environment and Pollution, vol. 22, No. 4, 2004.

QIN, Y.; TONNESEN, G.S.; WANG, Z. W. Weekend/weekday differences of ozone, NOx, Co, VOCs, PM10 and the light scatter during ozone season in southern California. Atmospheric Environment, 38 (3069-3087), 2004.

SEINFELD, J.H., PANDIS, S.N. Atmospheric Chemistry and Physics from Air Pollution to Climate Change. Wiley, New York, U.S.A, 1998.

TURPIN, B. Options for Characterizing Organic Particulate Matter. Environmental Science \& Technology, feb1, p. 76A-78A, 1999. 